\title{
Erratum to: Investigating the Effect of Water Uptake on the Tribological Properties of Organoclay Reinforced UHMWPE Nanocomposites
}

\author{
Abdul Samad Mohammed ${ }^{1} \cdot$ Annas Bin Ali ${ }^{1} \cdot$ Nesar Merah $^{1}$
}

Published online: 30 March 2016

(C) Springer Science+Business Media New York 2016

Erratum to: Tribol Lett (2016) 62:2

DOI 10.1007/s11249-016-0652-4

The original version of this article unfortunately contained a mistake. The third co-author's name (Nesar Merah) and his affiliation were missing in the original publication. Corrected order of authors and affiliations are provided here.

The online version of the original article can be found under doi: 10.1007/s11249-016-0652-4.

Abdul Samad Mohammed samad@kfupm.edu.sa

1 Mechanical Engineering Department, King Fahd University of Petroleum and Minerals, Dhahran, Saudi Arabia 